Çukurova Üniversitesi Mühendislik Mimarlık Fakültesi Dergisi, 34(2), ss. 121-133 Haziran 2019

Çukurova University Journal of the Faculty of Engineering and Architecture, 34(2), pp. 121-133, June 2019

\title{
Endüstriyel Ham Madde Atıklarının Dolgu Malzemesi Olarak Kullanılabilirliği
}

\author{
Gül KARAKILÇIK ${ }^{1}$, Sedat TÜRKMEN² \\ ${ }^{1}$ Karayolları 4. Bölge Müdürlüğ̈̈, Ankara \\ ${ }^{2}$ Çukurova Üniversitesi, Mühendislik Fakültesi, Jeoloji Mühendisliği Bölümü, Adana
}

$\ddot{\mathbf{O} z}$

Geliș tarihi: 22.03.2019 Kabul tarihi: 28.06.2019

Son yıllarda ekonomik ve teknolojik gelişmelere paralel olarak, endüstriyel katı atıkların miktarı ve çeşidi giderek artmaktadır. Bu çalı̧̧mada, endüstriyel katı atıkların değerlendirilmesi, ham madde olarak yeniden kullanılması ve tekrar ekonomiye kazandırılması amaçlanmaktadır. Bu amaç doğrultusunda, cam ham madde atı̆ğ (şlam) belli oranlarda kil malzemeyle karıştırılmış ve dolgu malzemesi olarak kullanılabilirliği değerlendirilmiştir. Çalışmada ayrıca uçucu külün, kil malzemeyle karıştııılması sonucu elde edilen özellikler özetlenmiştir.

Mersin İli, Akdeniz İlçesi, Sarıibrahimli Mahallesi bölgesinde bulunan Trakya Cam Fabrikası'na ait cam ham madde atı̆̆ (şlam) malzemesi, yine aynı bölgede yer alan ÇiMSA çimento ham maddesi ve Yumurtalık İsken Fabrikası'ndan çıkan uçucu kül malzemesi bu makalenin çalışma konusunu oluşturmaktadır.

Anahtar Kelimeler: Cam ham madde atığı (şlam), Uçucu kül, Çimento ham maddesi, Toprak dolgu malzemesi

\section{Usability of Industrial Raw Material Wastes as Filling Material}

\begin{abstract}
In parallel with economic and technological developments in recent years, the amount and variety of industrial solid wastes are increasing. In this study, it is aimed to evaluate industrial solid wastes, to reuse them as raw materials and to gain economy again. For this purpose, glass raw material wastes were mixed with clay materials at certain ratios and evaluated as usability as filling material. In study, the characteristics obtained by mixing fly ash and clay material are also summarized.

Glass raw material waste material belonging to Trakya Cam Factory located in Mersin province, Akdeniz district, Sarribrahimli neighbourhood area, ÇIMSA cement raw material located in the same region and fly ash material coming from the Yumurtalık Isken Factory constitute the study topic of this study.
\end{abstract}

Keywords: Glass raw material waste (şlam), Fly ash, Cement raw material, Earthfill material

*Sorumlu yazar (Corresponding author): Sedat TÜRKMEN, sturkmen@cu.edu.tr 


\section{GíRiș}

Sanayi ve üretim kuruluşlarında bir işlem sırası veya sonrasında meydana gelen katı atıklara endüstriyel katı atıklar adı verilir.

$\mathrm{Bu}$ atıkların üretildikleri yerlerden toplanması, geçici depolanması, taşınması ve yok edilmesi oldukça önemlidir. Geri kazanımı ve değerlendirilme imkanı olan atıkların çeşitli fiziksel veya kimyasal proseslerden geçirilerek yeniden ham maddeye dönüştürülerek tekrar üretim sürecine dahil edilmesi gerekmektedir. Doğal kaynaklar sonsuz olmadığı için yeniden kazanım doğanın dengesi için oldukça önemlidir.

Mersin ve civarında faaliyet gösteren cam fabrikalarından yılda 17.280.000 ton civarında atık malzeme (şlam) ortaya çıkmaktadır. Bu atık madde işletmeye her yıl taşıma, stoklama maliyeti getirmenin dişında çevresel problemler de oluşturmaktadır. Bu amaçla, Mersin ve civarındaki cam fabrikalarında kullanılan ham maddelerin zenginleştirilmesi sonucu ortaya çıkan atık malzemelerinin (şlam) yerel dolgu malzemeleriyle karıştırılarak, yine Mersin ve çevresinde faaliyet gösteren kimyasal üretim yapan, soda ve krom tesislerinin endüstriyel atıkları için yapılan atık barajlarının sedde dolgularında kullanılabilirliği araştırılmıştır.

$\mathrm{Bu}$ çalışmanın amacı; şlam adı verilen, maden veya endüstriyel ham madde zenginleştirilmesi veya depolanması sonucu oluşan katı killi malzemenin, dolgu yapımı için sorunlu olan yerel dolgu malzemesi ile karıştırılarak uygun dolgu malzemesi elde etmektir. Bu amaçla gerekli arazi ve laboratuvar çalışmaları yapılarak malzemenin kullanılabilirliği değerlendirilmiştir.

\section{2. ÖNCEKİ ÇALIŞMALAR}

Schmidt [1], İlker [2], Yetiş ve Demirkol [3], Şenol ve arkadaşları [4] Adana havzası ile ilgili yaptıkları çalışmalarda Adana-Mersin arasında Güvenç formasyonunun üzerinde çökelen Kuzgun formasyonunun yer yer karasal nitelikte yer yer ise sığ deniz ortamında çökeldiğini belirtmişlerdir.
Kavas ve arkadaşları [5] Cam Atıklarının Çimento Üretiminde Katkı Maddesi Olarak Kullanılabilirliğinin Araştırılması konusunda yaptıkları çalışmalarında, belirli tane boyutlarına kadar ögütülmüş cam atıklarının çimento üretiminde katkı maddesi olarak kullanılabilirliğini araştırmışlardır. Sakatoğlu [6], Menekşe Köyü (Karaisalı) killerinin Camiş Madencilik A.Ş. atıkları ile karıştırılarak Tuğla Yapılması Olanaklarının Araştırılması, konusundaki yüksek lisans tezinde, Karaisalı İlçesi Menekşe yöresi killerinin, yine yörede kurulu Camiş A.Ş. Fabrikasının atıkları ile tuğla yapılabilirliğini araştırmıştır. Ünal ve Uygunoğlu [7]. Soma Termik Santral Atığı Uçucu Külünün İnşaat Sektöründe Değerlendirilmesi, Atanur [8] Uçucu Küllerin Agrega-Çimento Karışımlarında Portland Çimentosunun yerine kullanılması gibi çalışmalar yapmışlardır. Alkaya [9] uçucu küllerin zemin iyileştirmesinde kullanılması konusunda, Erdoğan [10] atık malzemelerin inşaat endüstrisinde kullanımı konularında araştırmalar yapmışlardır.

Çavuşoğlu [11] "Uçucu Küllerin Dolgu Malzemesi Olarak Kullanılması: Örnek Bir Uygulama (Çayırhan)" isimli çalışmasında, yeraltı madencilik uygulamalarında, üretim yöntemine de bağlı olarak genellikle cevherin çıkarılmasıyla oluşan boşlukların dolgu malzemeleriyle doldurulmasından bahsetmiştir. Çuhadaroğlu [12], termik santrallerden çıkan uçucu küllerin tuğla üretiminde değerlendirilmesi ile ilgili çalışmalar yapmiştır.

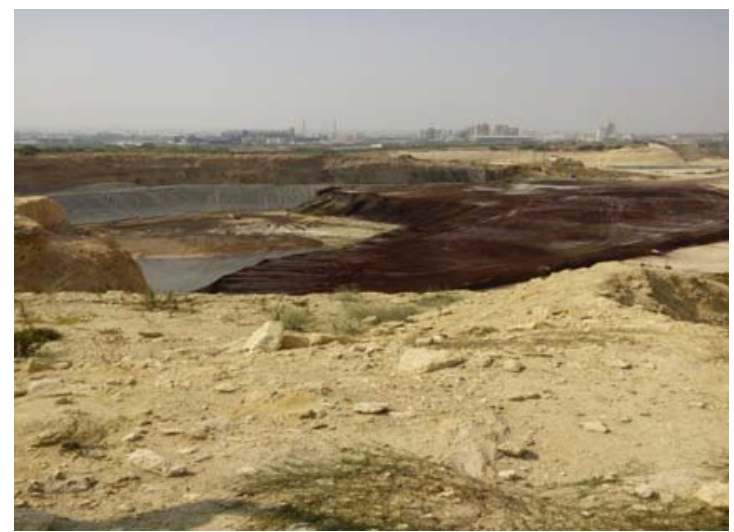

Şekil 1. Çalışma sahasından genel bir görünüm 


\section{MATERYAL VE METOD}

\subsection{Materyal}

Cam endüstrisinde kullanılan ham madde kuvarsit veya kuvars kumu olarak temin edilmektedir. Fabrikaya gelen ham madde kırma işlemine tabi tutularak $20 \mathrm{~mm}$ boyutuna getirilir. Öğütülen malzeme, cam kumu hazırlama tesisinde rslak eleme işleminden sonra geriye kalan ince taneli ve kil içeren atık malzeme şlam olarak ayrılır.

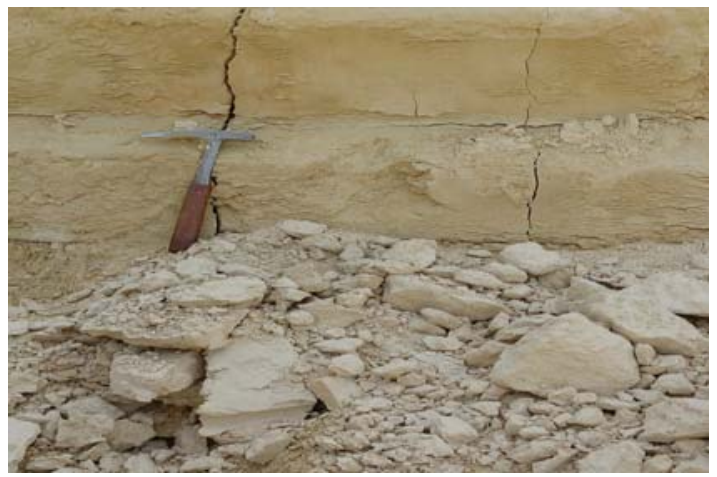

Şekil 2. Cam ham madde atı̆̆ı (şlam).

$\mathrm{Bu}$ çalışma kapsamında, endüstriyel atık malzemelerinin dolgu malzemesi olarak kullanımın tespiti amacıyla Mersin organize sanayi bölgesindeki cam fabrikasından çıkan kuvarsit atığı şlam numunesi kullanılmıştır. Ayrıca MersinSarıibrahimli mevkiindeki çimento fabrikasının kullandığı ham madde ocakları çevresindeki kazı artığ1 malzemeler yine bu çalışma kapsamında değerlendirilerek ana materyal olarak kullanılmıştır. Katkı malzemesi olarak da İsken Termik Santrali'nden alınan uçucu kül kullanılmıştır. Araziden alınan numuneler laboratuvara getirilerek, gerekli indeks ve mühendislik özelliklerinin belirlenmesine yönelik zemin deneyleri yapılmıştır.

\subsection{1. Ínceleme Alanı Jeolojisi}

İnceme alanı ve çevresinde, temeli oluşturan Paleozoyik ve Mesozoyik yaşlı birimler üzerinde çökelen Senozoyik yaşlı tortul kayaçlar egemendir. Miyosen'in değişik dönemlerine ait bu tortul kayaçlar değişik fasiyeslerde oluştukları için, litolojik olarak oldukça farklı yapıdadırlar. Yöredeki birimler; resifal kireçtaşı, kiltaşı-marn ardalanması ve kumtaşı-kiltaşı birimleri ile bu birimlerin üzerine gelen Kuvaterner yaşlı kaliçi ve güncel alüvyonlardan oluşur.

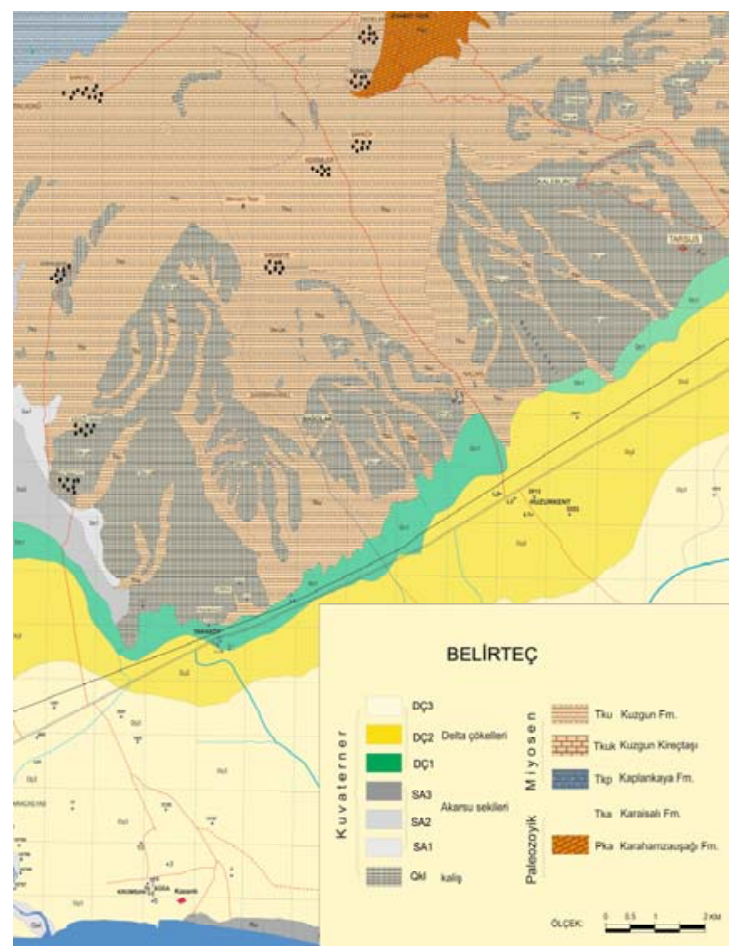

Şekil 3. Çalışma Alanı jeolojik haritası (Şenol ve arkadaşları [4]'den alınmıştır)

İnceleme alanı ve çevresinde, yeşilimsi, sarımsı beyaz, gri-siyah renk tonlarında gözlenen Kuzgun formasyonu resifal kireçtaşı, kumtaşı-konglomera, kiltaşı (şeyl)-silttaşı-marn gibi dört kaya biriminden oluşmuştur. Kuzgun formasyonu Güvenç formasyonu ile uyumlu olup üzerine geçişli olarak gelir. Kalınlığı yaklaşık 50-1500 metre arasında değişmekte olan Kuzgun formasyonu kıyı-sı̆g deniz ortamı koşullarında çökelmiştir. Formasyonun yaşı değişik araştırmacılar tarafından paleontolojik verilere dayanarak Tortoniyen-Messiniyen olarak verilmiştir [1-4]. Çalışma konusu olan çimento hammaddesi kuzgun formasyonuna ait marn, killi kireçtaşı ve kiltaşı litolojilerinden oluşmaktadır. 


\subsection{Metod}

$\mathrm{Bu}$ çalışma, literatür taraması, arazi çalışmaları, laboratuvar çalışmaları ve büro çalışmaları olmak üzere dört safhada gerçekleştirilmiştir. Arazi öncesi çalışmalarda, daha önce yapılmış olan çalışmalar incelenmiştir. Arazi çalışmaları olarak, arazi üzerinde incelemeler yapılmış ve laboratuvar çalışmaları için, hem cam ham madde atığı (şlam)'dan hem de çimento ham maddesinden örselenmiş numuneler alınmıştır.

\subsubsection{Arazi Çalışmaları}

$\mathrm{Bu}$ çalışmada, genel olarak arazi incelemesi yapılmış ve endüstriyel atık alanları incelenmiştir. Arazi üzerinden birkaç noktadan farklı numune örnekleri alınmıştır. Alınan örnek yerlerine ait koordinat noktaları belirlenmiştir. Gerekli durumlarda fotoğraflar çekilmiştir.

\subsubsection{Laboratuvar Çalışmaları}

Tüm numune örnekleri öncelikle saf olarak, sonra belli yüzdeler şeklinde karıştırılarak deneye tabi tutulmuştur. Deneyler Çukurova Üniversitesi Jeoloji Mühendisliği Bölümü Laboratuvarlarında yapılmıştır. Numuneler üzerinde; kesme kutusu deneyi, kompaksiyon deneyi, doğal birim hacim ağırlık testi, tane boyu (hidrometre ve elek) analizi, kıvam (Atterberg) limitleri deneyleri ve su içeriği tayini deneyleri yapılmıştır.

\section{ARAŞTIRMA BULGULARI}

\subsection{Numunelerin İndeks Özellikleri}

\subsection{2. Özgül Ă̆grlık Deneyi}

Çalışma sahasından alınan numuneler American Society of Testing Materials D 854-02 [13] standardına uygun olarak test edilerek her bir numuneye ait özgül ağırlık değeri tespit edilmiştir. $\mathrm{Bu}$ deney sonucunda özgül ağırlık; cam ham madde atığı (şlam) için 2,543, çimento ham maddesi için 2,583, cam ham madde atığ (şlam)çimento ham maddesi \%50 karışım için 2,516, çimento ham maddesi \%5 kül karışımı için 2,7, çimento ham maddesi \%10 kül karışımı için 2,68, çimento ham maddesi \%15 kül karışımı için 2,653 olarak bulunmuştur.

\subsubsection{Kıvam (Atterberg) Limitleri Deneyi}

Numuneler, American Society of Testing Materials ASTM D 4318-00 [14], standartında göre test edilerek kıvam limitleri belirlenmiştir. Çimento ham maddesi numunesinin likit limit (LL) değeri \%49,50, plastik limit (PL) değeri \%23,81, plastisite indisi (PI) değeri ise \%25,69'dur. Casagrande plastisite grafiği kullanılarak numunenin türü CL (Düşük-orta plastisiteli inorganik kil) olarak bulunmuştur.

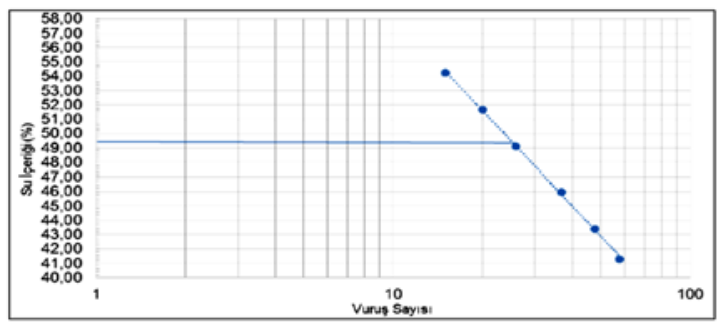

Şekil 4. Çimento ham madde pasasına ait likit limit (LL) değerinin bulunması

Cam ham madde atığı (şlam) numunesinin likit limit (LL) değeri \%28,30, plastik limit (PL) değeri $\% 19,61$, plastisite indisi (PI) değeri ise \%8,69'dur. Casagrande plastisite grafiği kullanılarak numunenin türü CL (Düşük-orta plastisiteli inorganik kil) olarak bulunmuştur.

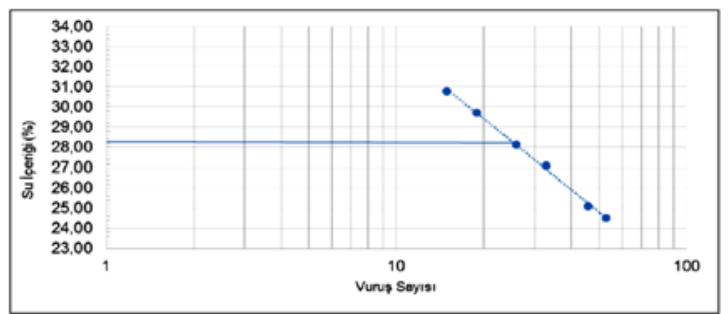

Şekil 5. Çimento ham madde pasası ait likit limit (LL) değerinin bulunması

Cam ham madde atığı (şlam)- $\% 50$ çimento ham maddesi numunesinin likit limit (LL) değeri $\% 41,80$, plastik limit (PL) değeri \%20,22, plastisite indisi (PI) değeri ise \%21,58'dir. Casagrande plastisite grafiği kullanılarak numunenin türü $\mathrm{CL}$ (orta plastisiteli inorganik kil) olarak bulunmuştur. 


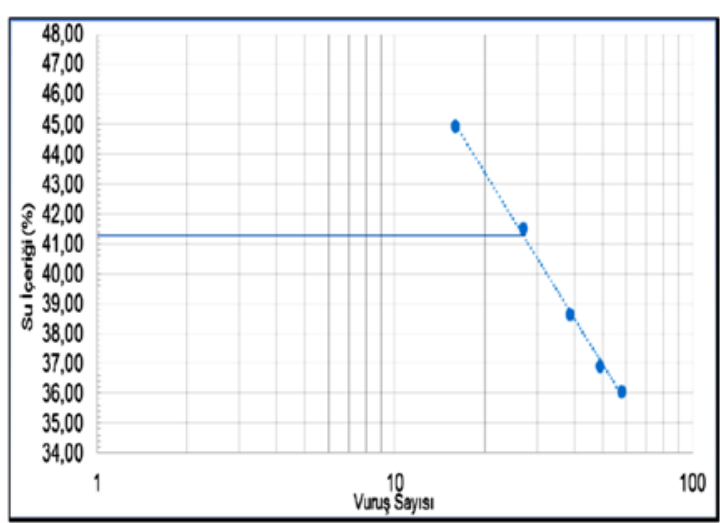

Şekil 6. Cam ham madde atığ (şlam)-\%50 çimento ham madde pasası numunesine ait likit limit (LL) değerinin bulunması

Çimento ham maddesi-\%5 kül karışımı numunesinin likit limit (LL) değeri \%48,80, plastik limit (PL) değeri \%25,96, plastisite indisi (PI) değeri ise \%23,54'tür. Casagrande plastisite grafiği kullanılarak numunenin türü CL (orta plastisiteli inorganik kil) olarak bulunmuştur.

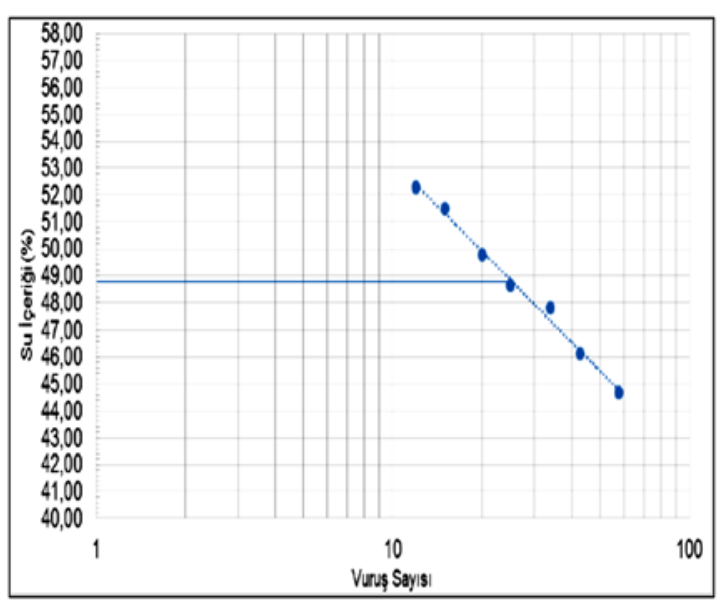

Şekil 7. Çimento ham madde pasas1-\%5 kül karışımı numunesine ait likit limit (LL) değerinin bulunması

Çimento ham maddesi-\%10 kül karışımı numunesinin likit limit (LL) değeri \%45,50, plastik limit (PL) değeri \%25,57, plastisite indisi (PI) değeri ise \%19,93'tür. Casagrande plastisite grafiği kullanılarak numunenin türü CL (orta plastisiteli inorganik kil) olarak bulunmuştur.

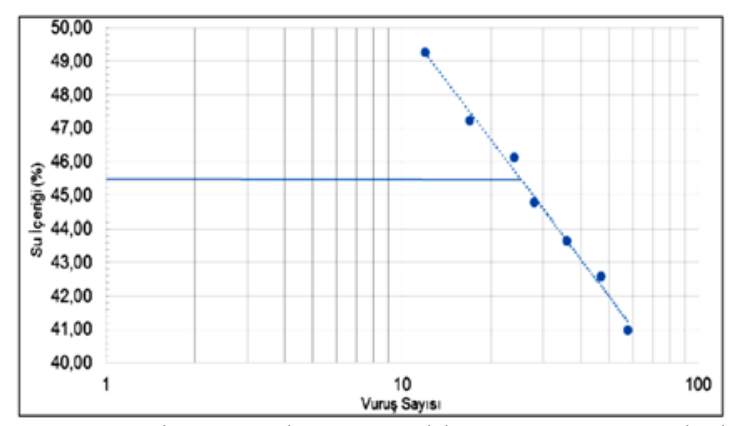

Şekil 8. Çimento ham madde pasası-\%10 kül karışımı numunesine ait likit limit (LL) değerinin bulunması

Çimento ham maddesi-\%15 kül karışımı numunesinin likit limit (LL) değeri \%44,65, plastik limit (PL) değeri \%24,83, plastisite indisi (PI) değeri ise \%19,82'dir. Casagrande plastisite grafiği kullanılarak numunenin türü CL (orta plastisiteli inorganik kil) olarak bulunmuştur.

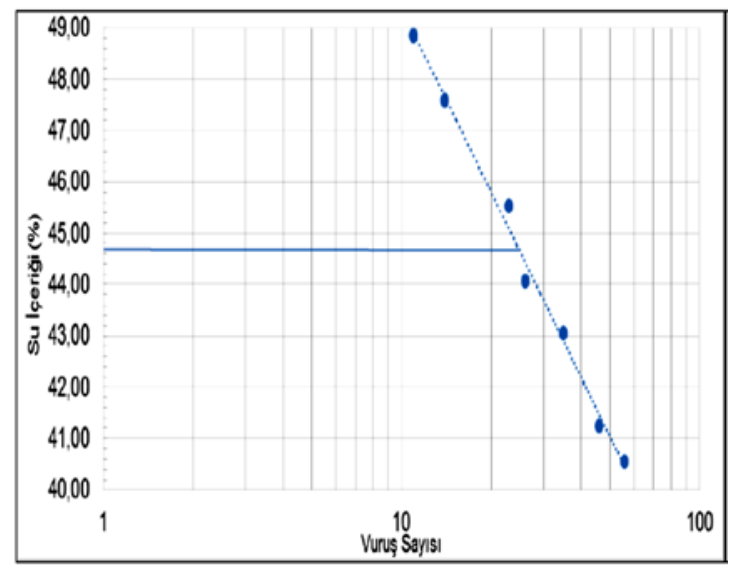

Şekil 9. Çimento ham madde pasası-\%15 Kül karışımı numunesine ait likit limit (LL) değerinin bulunması

\subsubsection{Tane Boyu Analizi Deneyi}

Tane boyu analizleri American Society of Testing Materials ASTM D 422-63 [15] standartında yapılmıştır. Çimento ham maddesi numunesine ait tane boyu analizinin, hidrometre analizi sonucunda; kil $\% 53,32$, silt $\% 36,17$, elek analizi sonucunda; kum \%10,29, çakıl \%0,22 olarak bulunmuştur. 


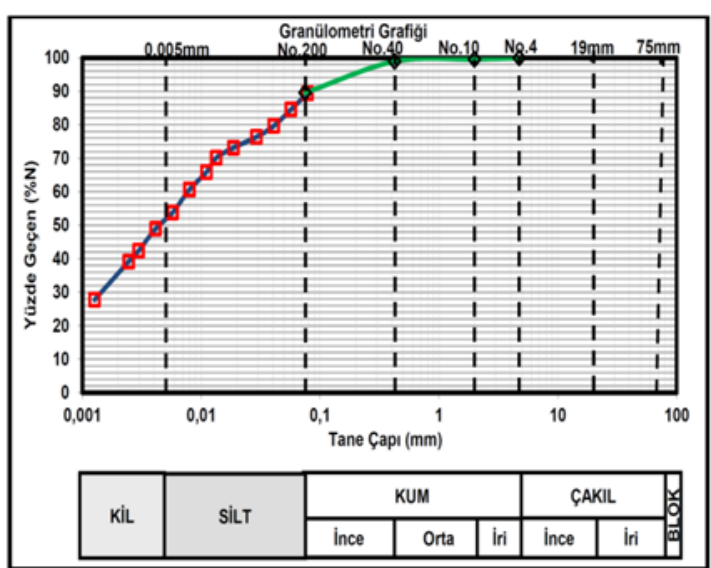

Şekil 10. Çimento ham madde pasası numunesine ait tane boyu dağılım grafiğgi

Cam ham madde atığı (şlam) numunesine ait tane boyu analizinin, hidrometre analizi sonucunda; kil $\% 22,58$, silt $\% 67,42$, elek analizi sonucunda; kum $\% 9,99$, çakıl \%0,01 olarak bulunmuştur.

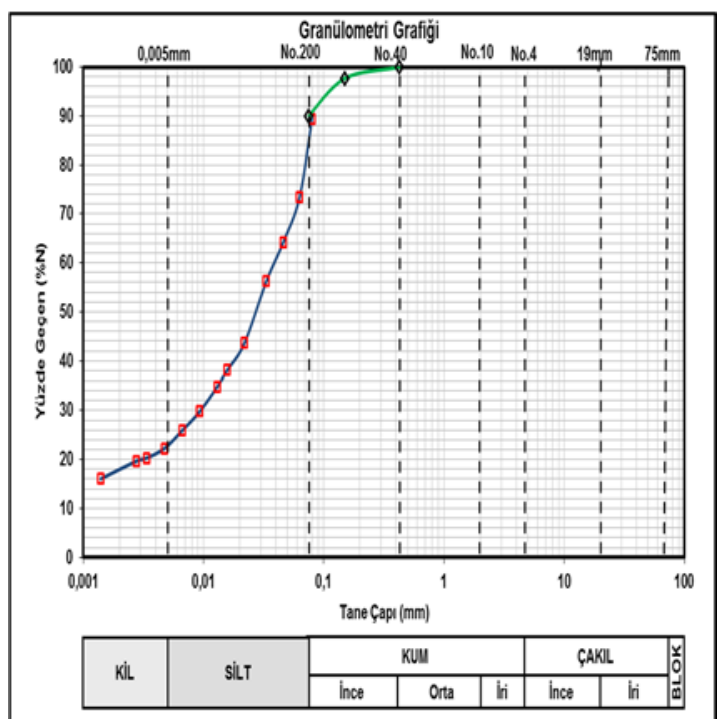

Şekil.11. Cam ham madde atığı (şlam) numunesine ait tane boyu dağılım grafiği

Cam ham madde atı̆̆ (şlam)-çimento ham maddesi \%50 karışım numunesine ait tane boyu analizinin, hidrometre analizi sonucunda; kil $\% 28,20$, silt $\% 57,8$, elek analizi sonucunda; kum $\% 13,92$, çakıl \%0,08 olarak bulunmuştur.

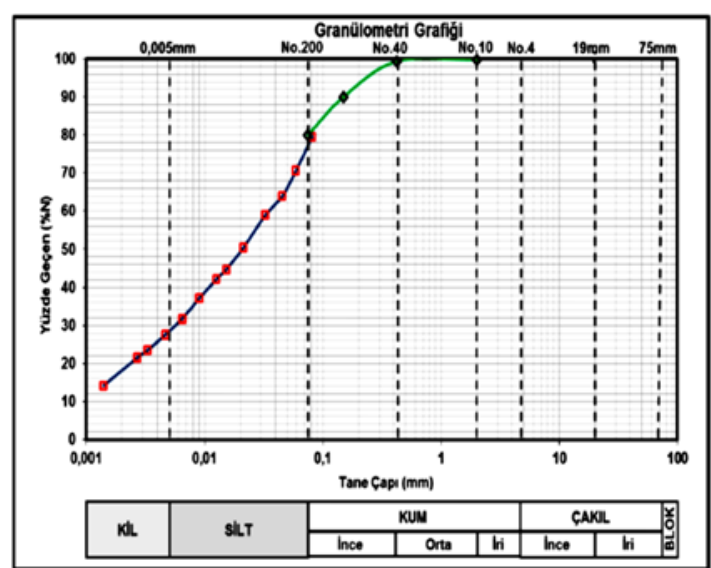

Şekil 12. Cam ham madde atı̆̆ı (şlam)-çimento ham madde pasası \%50 karışım numunesine ait tane boyu dağılım grafiği

Çimento ham maddesi-\%5 kül karışım numunesine ait tane boyu analizinin, hidrometre analizi sonucunda; kil \%56,38, silt \%33,84, elek analizi sonucunda; kum \%9,7, çakıl \%0,08 olarak bulunmuştur.

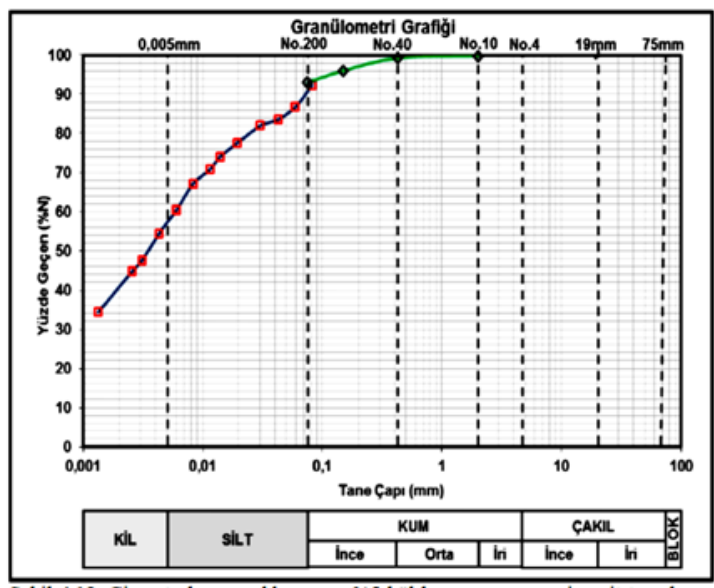

Şekil 13. Çimento ham madde pasas1- $\% 5$ kül karışım numunesine ait tane boyu dağılım grafiği

Çimento ham maddesi-\%10 kül karışım numunesine ait tane boyu analizinin, hidrometre analizi sonucunda; kil $\% 56,37$, silt $\% 37,63$, elek analizi sonucunda; kum \%5,93, çakı1 \%0,07 olarak bulunmuştur. 


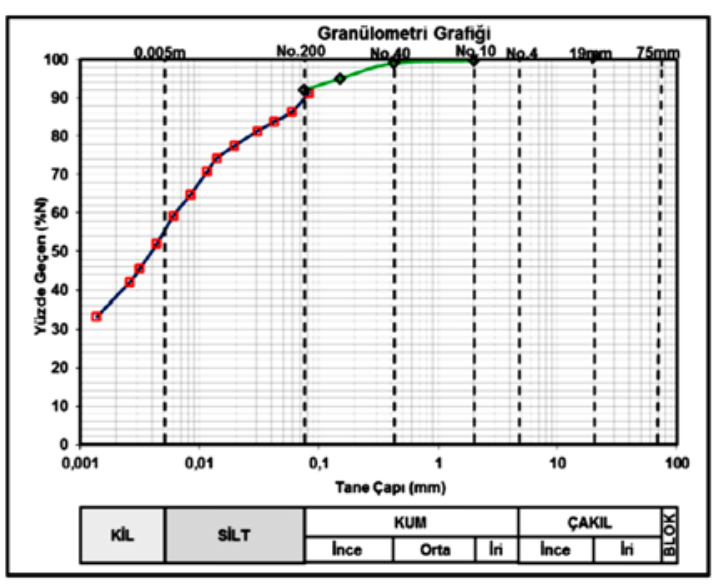

Şekil 14. Çimento ham madde pasas1-\%10 kül karışım numunesine ait tane boyu dağılım grafiği

Çimento ham maddesi-\%15 kül karışım numunesine ait tane boyu analizinin, hidrometre analizi sonucunda; kil $\% 54,83$, silt $\% 37,67$, elek analizi sonucunda; kum \%7,44, çakıl \%0,06 olarak bulunmuştur.

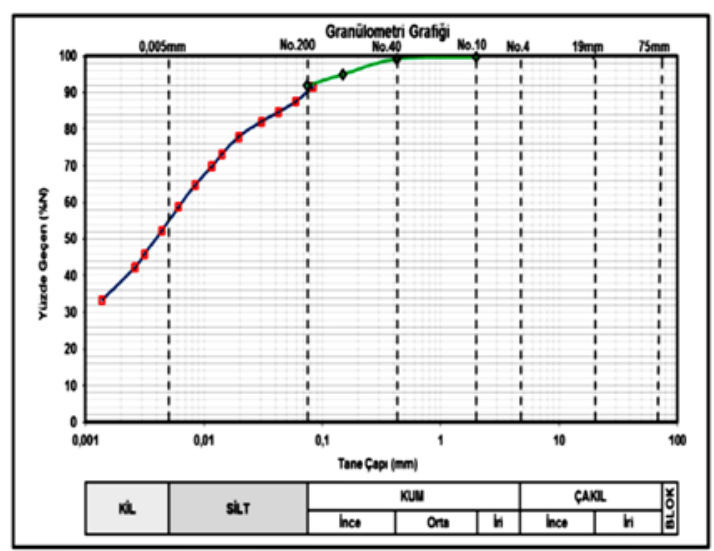

Şekil 15. Çimento ham madde pasas1-\%15 kül karışım numunesine ait tane boyu dağılım grafiği

\subsubsection{Standart Proctor (kompaksiyon) Deneyi}

Standart Proktor deneyi American Society of Testing Materials ASTM D 698-00a [16], standartına uygun kompaksiyon aleti ile gerçekleştirilmiş ve elde edilen veriler aşağıdaki gibidir.
Çimento ham maddesi numunesine ait optimum su içeriği (Wopt) \%20,5 olarak bulunmuştur. Optimum su içeriğine karşılık gelen maksimum kuru birim hacim ağırlı değeri $\left(\gamma_{\mathrm{kmax}}\right)$ ise $1,507 \mathrm{~g} / \mathrm{cm}^{3}$ olarak bulunmuştur.

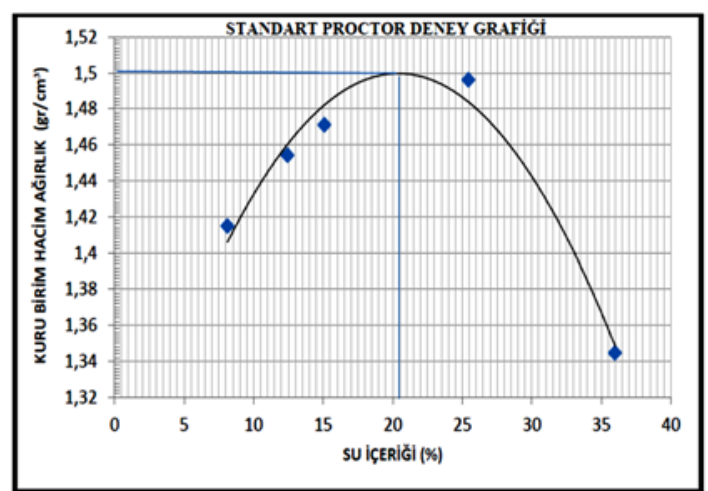

Şekil 16. Çimento ham madde pasası numunesi kompaksiyon eğrisi

Cam ham madde atı̆̆ 1 (şlam) numunesine ait optimum su içeriği (Wopt) \%14,5 olarak bulunmuştur. Optimum su içeriğine karşılık gelen maksimum kuru birim hacim ağırlık değeri $\left(\gamma_{\mathrm{kmax}}\right)$ ise $1,715 \mathrm{gr} / \mathrm{cm}^{3}$ olarak bulunmuştur.

Cam ham madde atığı (şlam)-çimento ham maddesi \%50 karışım numunesine ait optimum su içeriği (Wopt) \%15 olarak bulunmuştur. Optimum su muhtevasına karşılık gelen en yüksek kuru birim hacim ağırlık değeri $\left(\gamma_{\mathrm{kmax}}\right)$ ise $1,578 \mathrm{~g} / \mathrm{cm}^{3}$ olarak bulunmuştur.

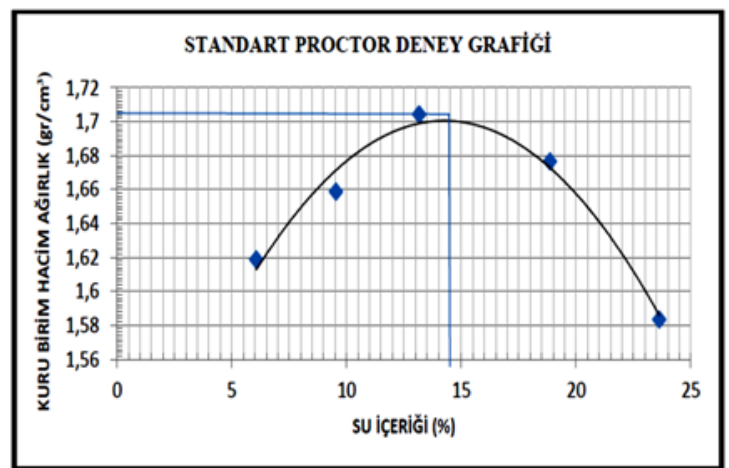

Şekil 17. Cam ham madde atığg (şlam) numunesi kompaksiyon eğrisi 


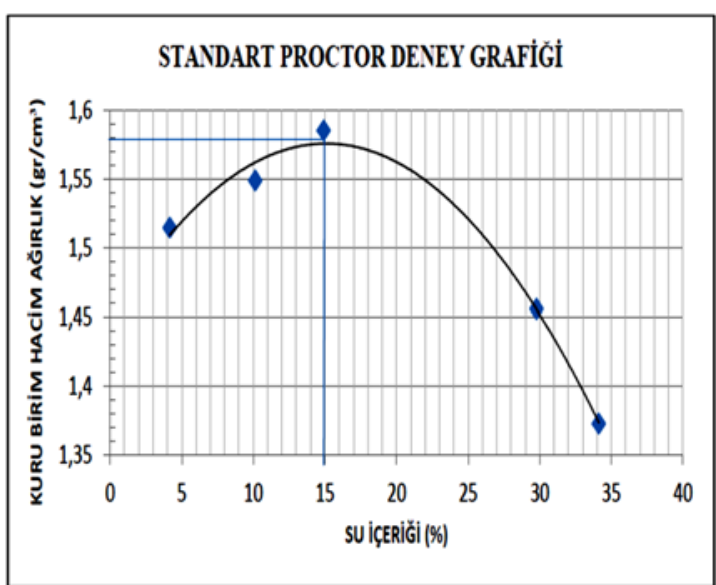

Şekil 18. Cam ham madde atığı (şlam)-çimento ham madde pasası \%50 karışım numunesi kompaksiyon eğrisi

Çimento ham maddesi-\%5 kül karışım numunesine ait optimum su içeriği (Wopt) \%11,57 olarak bulunmuştur. Optimum su muhtevasına karşılık gelen en yüksek kuru birim hacim ağırlık değeri $\left(\gamma_{\mathrm{kmax}}\right)$ ise $1,67 \mathrm{~g} / \mathrm{cm}^{3}$ olarak bulunmuştur.

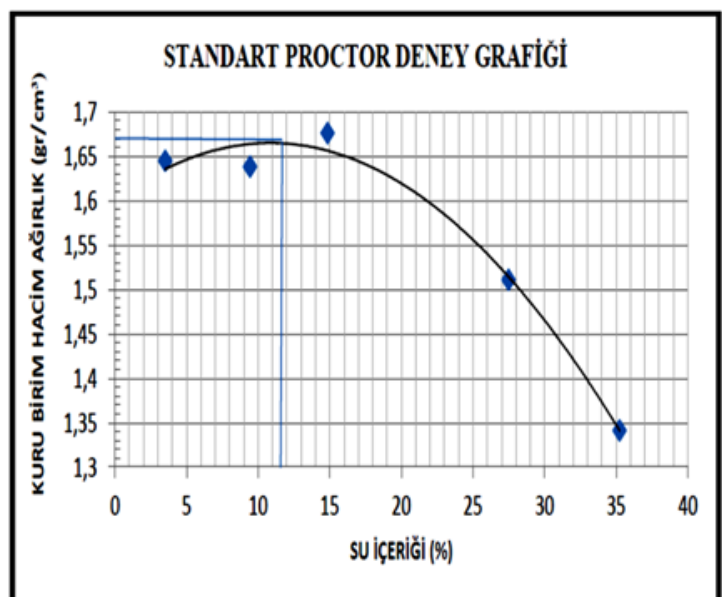

Şekil 19. Çimento ham madde pasası-\%5 kül karışımı numunesi kompaksiyon eğrisi

Çimento ham maddesi-\%10 kül karışım numunesine ait optimum su içeriği (Wopt) \%14 olarak bulunmuştur. Optimum su muhtevasına karşılık gelen en yüksek kuru birim hacim ağırlık değeri $\left(\gamma_{\mathrm{kmax}}\right)$ ise $1,638 \mathrm{~g} / \mathrm{cm}^{3}$ olarak bulunmuştur.

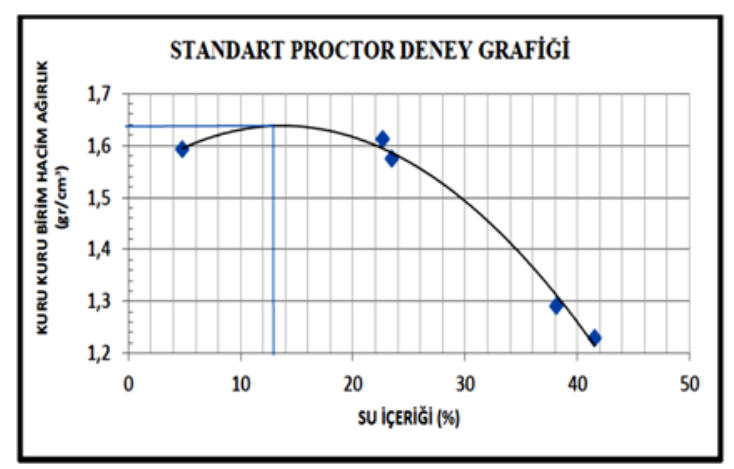

Şekil 20. Çimento ham madde pasası-\%10 kül karışımı numunesi kompaksiyon eğrisi

Çimento ham maddesi-\%15 kül karışım numunesine ait optimum su içeriği ( Wopt) \%14,95 olarak bulunmuştur. Optimum su muhtevasına karşılık gelen en yüksek kuru birim hacim ağırlık değeri $\left(\gamma_{\mathrm{kmax}}\right)$ ise $1,618 \mathrm{~g} / \mathrm{cm}^{3}$ olarak bulunmuştur.

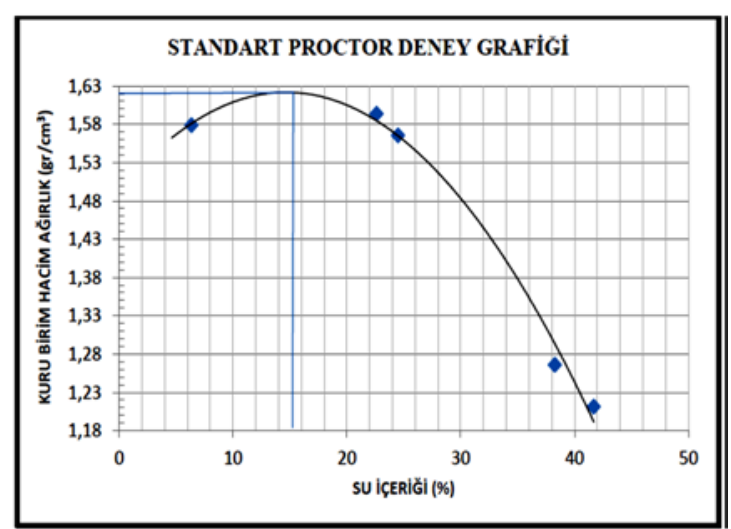

Şekil 21. Çimento ham madde pasası-\%15 kül karışımı numunesi kompaksiyon eğrisi

\subsubsection{Kesme Kutusu Deneyi}

Kesme kutusu deneyi American Society of Testing Materials ASTM D 3080-98, [17], standartlarındaki test düzeneğinde yapılmıştır. Zeminlerin kayma direnci üç temel parametreden oluşmaktadır. $\mathrm{Bu}$ parametreler; zemin tanelerinin birbirine kenetlenmesi, kohezyon ve sürtünme olarak sıralanabilir. Zeminlerin kohezyonsuz ya da kohezyonlu olması, yapılan kesme kutusu deneyinin konsolidasyon ve drenaj koşulları kayma direncine etki eden nedenler arasındadır. 
Çimento ham maddesi örneği üzerinde yapılan kesme kutusu deneyinde $2 \mathrm{~kg}$ $\left(\sigma \mathrm{n}=0,556 \mathrm{~kg} / \mathrm{cm}^{2}\right)^{\prime} l \mathrm{lk}$ normal yük altında maksimum kesme gerilmesi $0,27 \mathrm{~kg} / \mathrm{cm}^{2}, 4 \mathrm{~kg}$ $\left(\sigma \mathrm{n}=1,11 \mathrm{~kg} / \mathrm{cm}^{2}\right)^{\prime} \mathrm{l} 1 \mathrm{k}$ normal yük altında maksimum kesme gerilmesi $0,77 \mathrm{~kg} / \mathrm{cm}^{2}$ ve $8 \mathrm{~kg}$ $\left(\sigma \mathrm{n}=2,22 \mathrm{~kg} / \mathrm{cm}^{2}\right)^{\prime} l \mathrm{lk}$ normal yük altında maksimum kesme gerilmesi $1,31 \mathrm{~kg} / \mathrm{cm}^{2}$ olarak bulunmuştur. Çimento ham maddesi numunesinin kesme kutusu deneyinden elde edilen sonuçlara göre kırılma zarfi grafiği çizilmiş kohezyon (c) $0,005 \mathrm{~kg} / \mathrm{cm}^{2}$ ve içsel sürtünme açısı (ø) $31,17^{\circ}$ olarak bulunmuştur.
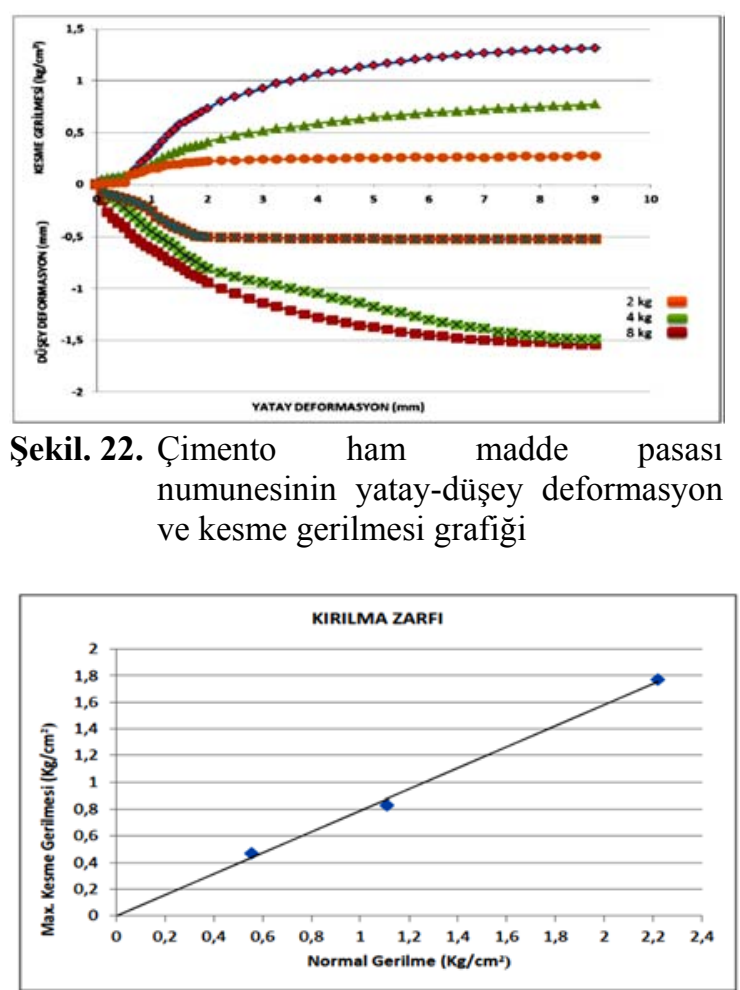

Şekil 23. Çimento ham madde pasası numunesinin kırılma zarfı grafiği

Cam ham madde atığı (şlam) örnekleri üzerinde yapilan kesme kutusu deneyinde $2 \mathrm{~kg}$ $\left(\sigma \mathrm{n}=0,556 \mathrm{~kg} / \mathrm{cm}^{2}\right)^{\prime} l \mathrm{lk}$ normal yük altında maksimum kesme gerilmesi $0,47 \mathrm{~kg} / \mathrm{cm}^{2}, 4 \mathrm{~kg}$ $\left(\sigma \mathrm{n}=1,11 \mathrm{~kg} / \mathrm{cm}^{2}\right)^{\prime} \mathrm{l} \mathrm{k}$ normal yük altında maksimum kesme gerilmesi $0,83 \mathrm{~kg} / \mathrm{cm}^{2}$ ve $8 \mathrm{~kg}$ $\left(\sigma \mathrm{n}=2,22 \mathrm{~kg} / \mathrm{cm}^{2}\right)^{\prime} \mathrm{l} \mathrm{k}$ normal yük altında maksimum kesme gerilmesi $1,77 \mathrm{~kg} / \mathrm{cm}^{2}$ olarak bulunmuştur. Cam ham madde atığ1 (şlam) numunesinin kesme kutusu deneyinden elde edilen sonuçlara göre kırılma zarfı grafiği çizilmiş kohezyon (c) $0,002 \mathrm{~kg} / \mathrm{cm}^{2}$ ve içsel sürtünme açıs1 (ø) $38,26^{\circ}$ olarak bulunmuştur.

Cam ham madde atı̆̆ı (şlam)-çimento ham maddesi \%50 karışım numunesi üzerinde yapılan kesme kutusu deneyinde $2 \mathrm{~kg}$ $\left(\sigma \mathrm{n}=0,556 \mathrm{~kg} / \mathrm{cm}^{2}\right)^{\prime} \mathrm{l} \mathrm{k}$ normal yük altında maksimum kesme gerilmesi $0,48 \mathrm{~kg} / \mathrm{cm}^{2}, 4 \mathrm{~kg}$ $\left(\sigma \mathrm{n}=1,11 \mathrm{~kg} / \mathrm{cm}^{2}\right)^{\prime} \mathrm{l} \mathrm{k}$ normal yük altında maksimum kesme gerilmesi $0,86 \mathrm{~kg} / \mathrm{cm}^{2}$ ve $8 \mathrm{~kg}$ $\left(\sigma \mathrm{n}=2,22 \mathrm{~kg} / \mathrm{cm}^{2}\right)^{\prime} \mathrm{l} \mathrm{k}$ normal yük altında maksimum kesme gerilmesi $1,54 \mathrm{~kg} / \mathrm{cm}^{2}$ olarak bulunmuştur. Cam ham madde atığı (şlam)çimento ham maddesi \%50 karışım numunesinin kesme kutusu deneyinden elde edilen sonuçlara göre kırılma zarfı grafiği çizilmiş kohezyon (c) $0,14 \mathrm{~kg} / \mathrm{cm}^{2}$ ve içsel sürtünme açısı (Ø) $32,35^{0}$ olarak bulunmuştur.

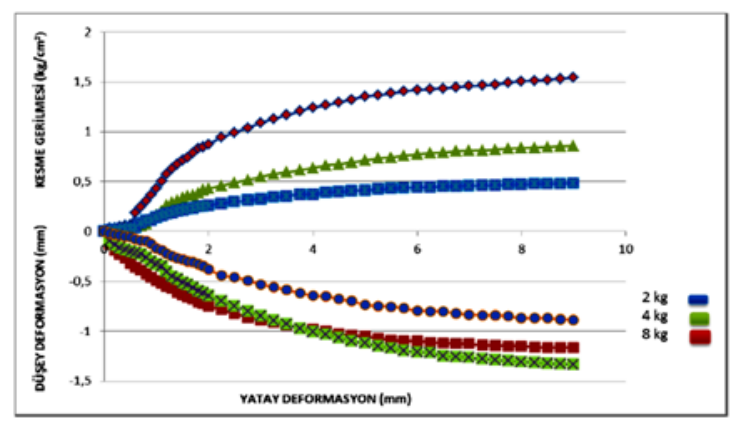

Şekil 24. Cam ham madde atığı (şlam) numunesinin yatay-düşey deformasyon ve kesme gerilmesi grafiği

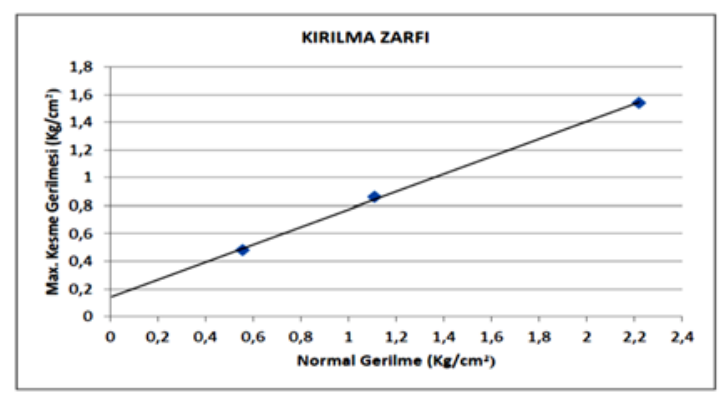

Şekil 25. Cam ham madde atığı (şlam) numunesinin kırılma zarfı grafiği 
Çimento ham maddesi \%5 kül karışım numunesi üzerinde yapılan kesme kutusu deneyinde $2 \mathrm{~kg}$ $\left(\sigma \mathrm{n}=0,556 \mathrm{~kg} / \mathrm{cm}^{2}\right)^{\prime} l \mathrm{k}$ normal yük altında maksimum kesme gerilmesi $0,44 \mathrm{~kg} / \mathrm{cm}^{2}, 4 \mathrm{~kg}$ $\left(\sigma \mathrm{n}=1,11 \mathrm{~kg} / \mathrm{cm}^{2}\right)^{\prime} \mathrm{l} \mathrm{lk}$ normal yük altında maksimum kesme gerilmesi $0,9 \mathrm{~kg} / \mathrm{cm}^{2}$ ve $8 \mathrm{~kg}$ $\left(\sigma \mathrm{n}=2,22 \mathrm{~kg} / \mathrm{cm}^{2}\right)^{\prime} l \mathrm{l} \mathrm{k}$ normal yük altında maksimum kesme gerilmesi $1,46 \mathrm{~kg} / \mathrm{cm}^{2}$ olarak bulunmuştur. Çimento ham maddesi \%5 kül karışım numunesinin kesme kutusu deneyinden elde edilen sonuçlara göre kırılma zarfı grafiği çizilmiş kohezyon (c) $0,16 \mathrm{~kg} / \mathrm{cm}^{2}$ ve içsel sürtünme açısı (Ø) $30,85^{\circ}$ olarak bulunmuştur.

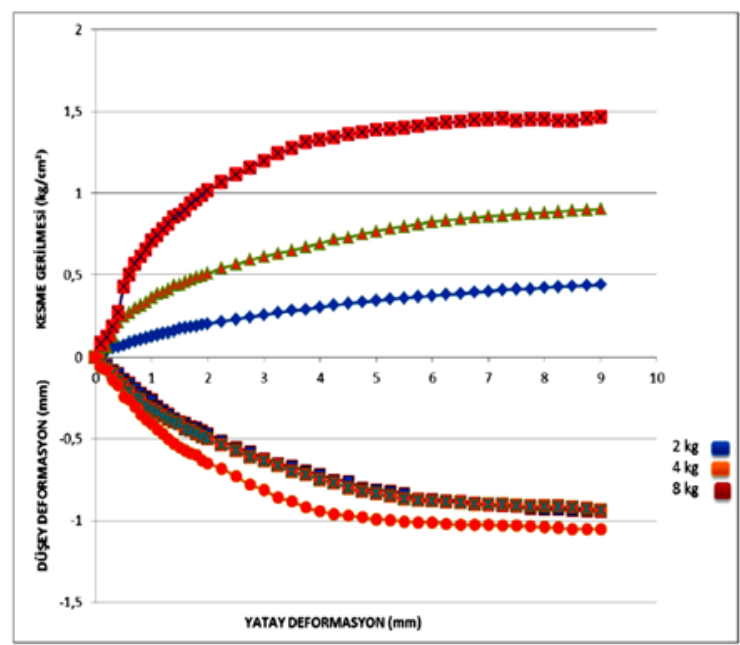

Şekil 26. Cam ham madde atığı (şlam)-çimento ham madde pasası $\% 50$ karışım numunesinin yatay-düşey deformasyon ve kesme gerilmesi grafiği

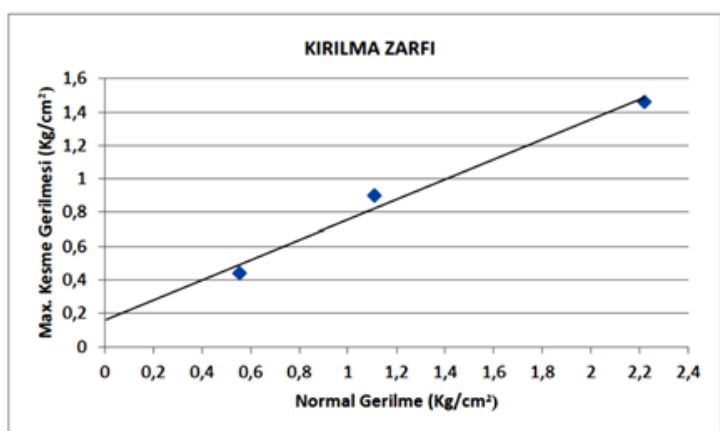

Şekil 27. Cam ham madde atığı (şlam)-çimento ham madde pasası \%50 karışım numunesinin kırılma zarfı grafiği
Çimento ham maddesi \%10 kül karışım numunesi üzerinde yapılan kesme kutusu deneyinde $2 \mathrm{~kg}$ $\left(\sigma \mathrm{n}=0,556 \mathrm{~kg} / \mathrm{cm}^{2}\right.$ ) normal yük altında maksimum kesme gerilmesi $0,39 \mathrm{~kg} / \mathrm{cm}^{2}, \quad 4 \quad \mathrm{~kg}$ $\left(\sigma n=1,11 \mathrm{~kg} / \mathrm{cm}^{2}\right)^{\prime} l 1 \mathrm{k}$ normal yük altında maksimum kesme gerilmesi $0,78 \mathrm{~kg} / \mathrm{cm}^{2}$ ve $8 \mathrm{~kg}$ $\left(\sigma \mathrm{n}=2,22 \mathrm{~kg} / \mathrm{cm}^{2}\right)^{\prime} \mathrm{l} \mathrm{k}$ normal yük altında maksimum kesme gerilmesi $1,35 \mathrm{~kg} / \mathrm{cm}^{2}$ olarak bulunmuştur. Çimento ham maddesi \%10 kül karışım numunesinin kesme kutusu deneyinden elde edilen sonuçlara göre kırılma zarfi grafiği çizilmiş kohezyon (c) $0,10 \mathrm{~kg} / \mathrm{cm}^{2}$ ve içsel sürtünme açısı (Ø) 29,59 olarak bulunmuştur.

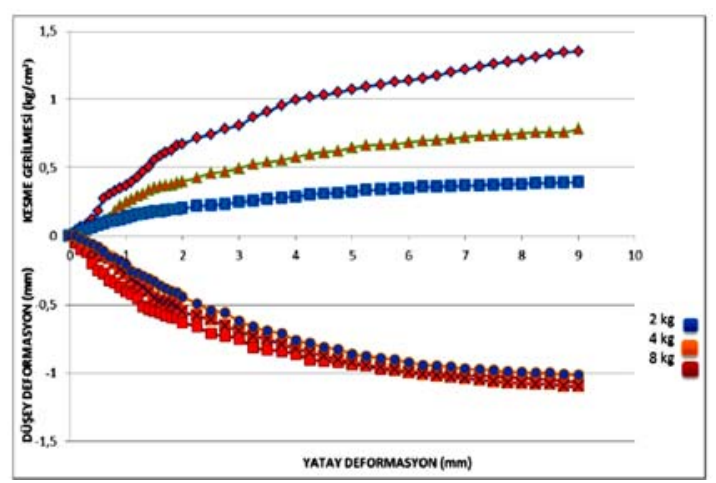

Şekil 28. Çimento ham madde pasas1-\%5 kül karışım numunesi yatay-düşey deformasyon ve kesme gerilmesi grafiği

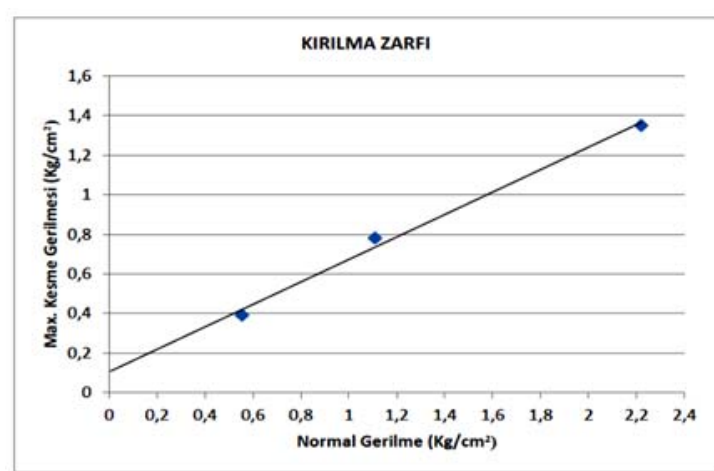

Şekil 29. Çimento ham madde pasas1- $\% 5$ kül karışım numunesi kırılma zarfı grafiği

Çimento ham maddesi \%15 kül karışım numunesi üzerinde yapılan kesme kutusu deneyinde $2 \mathrm{~kg}$ $\left(\sigma \mathrm{n}=0,556 \mathrm{~kg} / \mathrm{cm}^{2}\right)^{\prime} \mathrm{l} \mathrm{k}$ normal yük altında maksimum kesme gerilmesi $0,316 \mathrm{~kg} / \mathrm{cm}^{2}, 4 \mathrm{~kg}$ 
$\left(\sigma \mathrm{n}=1,11 \mathrm{~kg} / \mathrm{cm}^{2}\right)^{\prime} \mathrm{l} \mathrm{k}$ normal yük altında maksimum kesme gerilmesi $0,725 \mathrm{~kg} / \mathrm{cm}^{2}$ ve $8 \mathrm{~kg}$ $\left(\sigma \mathrm{n}=2,22 \mathrm{~kg} / \mathrm{cm}^{2}\right)^{\prime} \mathrm{l} \mathrm{k}$ normal yük altında maksimum kesme gerilmesi $1,356 \mathrm{~kg} / \mathrm{cm}^{2}$ olarak bulunmuştur. Çimento ham maddesi \%15 kül karışım numunesinin kesme kutusu deneyinden elde edilen sonuçlara göre kırılma zarfı grafiği çizilmiş kohezyon (c) $0,001 \mathrm{~kg} / \mathrm{cm}^{2}$ ve içsel sürtünme açısı (Ø) $31,66^{\circ}$ olarak bulunmuştur.

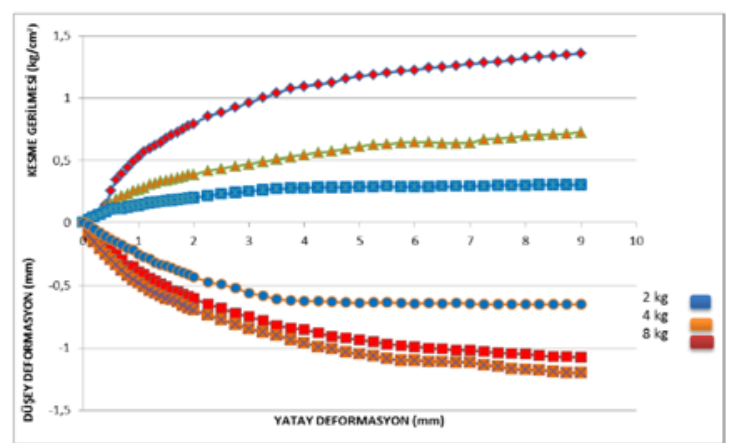

Şekil 30. Çimento ham madde pasası-\%10 kül karışım numunesi yatay-düşey deformasyon ve kesme gerilmesi grafiğ $i$

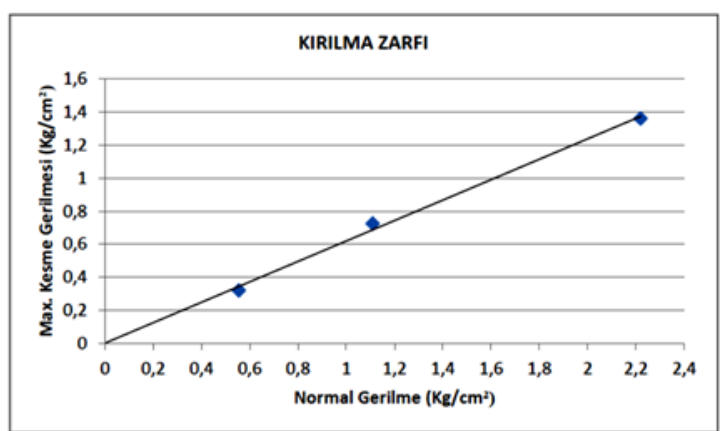

Şekil 31. Çimento ham madde pasas1-\%10 kül karışım numunesi kırılma zarfı grafiği

\section{TARTIŞMA VE SONUÇLAR}

Sanayideki gelişmelere paralel olarak, beraberinde birçok çevresel sorunlar da ortaya çıkmıştır. Bu sorunların önemli bir kolu da özellikle endüstri tesislerinde proses atıkları olarak ortaya çıkan katı atık maddelerdir. Günümüzde tüm gelişmiş ve gelişmekte olan ülkelerde katı atıklar sosyal, ekonomik ve çevresel sorunların önemli kısmını oluşturmaktadır. Ortaya çıkan atıkların bir bölümü tekrar kazanılabilir atıklar olup, çeşitli işlemlerle geri kullanıma sunulmalıdır.

$\mathrm{Bu}$ çalışma sonucunda kullanılan cam ham madde atığı (şlam), çimento ham maddesi ve çimento ham maddesine eklenen $\% 5, \% 10$ ve $\% 15$ uçucu kül katk1 malzemeli numunelerin USCS zemin sınıflamasına göre CL zemin tipine sahip olduğu belirlenmiştir.

Numunelerin plastisite indislerine bakıldığında cam ham madde atığının düşük plastisite değerine sahip olduğu çimento ham maddesinin ise yüksek plastik özelliğe sahip olduğu saptanmıştır. Bu iki numunenin \%50 karışımı ise yine plastik özellik göstermektedir. Cam ham madde atığının tek başına kuru dayanımının düşük olduğu ve dolgu malzemesi olarak kullanılabilirliği açısından zayıf bir malzeme olduğu saptanmıştır. Dayanımı düşük ve plastisitesi yüksek çimento ham maddesi ile cam ham madde atığının \%50 karıştırıldığında dayanımının attığı görülmüştür. Ayrıca çimento ham maddesine katkı malzemesi olarak ilave edilen $\% 5$ oranındaki uçucu kül miktarının plastik limit değerinin artmasına neden olduğu tespit edilmiştir. Fakat uçucu kül miktarının sırasıyla $\% 10$ ve $\% 15$ seviyesine çıkarılmasıyla plastik limit değerinin tekrar düştüğü, plastisitenin azaldığı görülmüştür.

Cam ham madde atığ 1 (şlam) numunesinin Proktor deneyi sonuçlarına bakıldığında, en yüksek kuru birim hacim ağırlığ $1,715 \mathrm{~g} / \mathrm{cm}^{3}$, çimento ham maddesine ait en yüksek kuru birim hacim ağırlık değeri ise $1,507 \mathrm{~g} / \mathrm{cm}^{3}$ olarak tespit edilmiştir. $\mathrm{Bu}$ iki numunenin \%50 oranında karışımı sonucu en yüksek kuru birim hacim ağırlığı $1,578 \mathrm{~g} / \mathrm{cm}^{3}$ olarak tespit edilmiştir. Çimento ham maddesine \%5 oranında uçucu kül katkısı ilavesiyle en yüksek kuru birim hacim ağırlığı 1,670 g/ $\mathrm{cm}^{3}$ seviyesine çıkmıştır. Uçucu kül miktarının $\% 10$ ve $\% 15$ seviyelerine çıkarılmasıyla en yüksek kuru birim hacim ağırlığ 1 sırasıyla $1,638 \mathrm{~g} / \mathrm{cm}^{3}$ ve $1,618 \mathrm{~g} / \mathrm{cm}^{3}$ seviyesine düşmüştür.

Cam ham madde atığı (şlam) numunesinin içsel sürtünme açısının yüksek $\left(\varnothing=38,26^{\circ}\right)$, kohezyon değerinin ise düşük $\left(\mathrm{c}=0,002 \mathrm{~kg} / \mathrm{cm}^{2}\right)$ olduğu görülmektedir. Çimento ham maddesi numunesi 
ise daha düşük içsel sürtünme açısı $\left(\varnothing=31,17^{\circ}\right)$ ve düşük kohezyon $\left(\mathrm{c}=0,005 \quad \mathrm{~kg} / \mathrm{cm}^{2}\right)$ değerine sahiptir. $\mathrm{Bu}$ iki numunenin $\% 50$ karışımı $0,14 \mathrm{~kg} / \mathrm{cm}^{2}$ kohezyon ve $32,35^{\circ}$ içsel sürtünme açısına sahiptir. Böylelikle bu karışımın kohezyon değerini artırdığı görülmüştür.

Çimento ham maddesi numunesine $\% 5$ oranında uçucu kül eklenmesiyle kohezyon değerinde önce bir artış $\left(0,16 \mathrm{~kg} / \mathrm{cm}^{2}\right)$ görülmüş, daha sonra $\% 10$ ve $\% 15$ oranında eklenen uçucu külün kohezyon değerini düşürdüğü (sırasıyla $0,1 \mathrm{~kg} / \mathrm{cm}^{2}$ ve $0,001 \mathrm{~kg} / \mathrm{cm}^{2}$ ) görülmüştür. İçsel sürtünme açıs değerinin ise eklenen uçucu kül oranlarına göre önce düştüğü sonra yükseldiği görülmektedir.

Yapılan deneyler ve çalışmalar sonucunda, cam ham madde atı̆̆ (şlam) numunesinin çimento ham maddesi ile $\% 50$ oranında karışımı ile oluşan malzemenin, dolgu malzemesi olarak kullanıma uygun olduğu tespit edilmiştir. Ayrıca, çimento ham maddesi numunesine uçucu külün katkı malzemesi olarak katılabileceği ve $\% 5$ uçucu kül katkısıyla en yüksek mukavemet değerlerine ulaşılabileceği sonucuna varılmıştır.

Sonuç olarak Mersin civarında var olan sanayi tesislerinden ortaya çıkan endüstriel atıkların ki bunlar çimento hammadde atığı, cam hammadde atı̆̆ı (şlam) ve termik santrallerden ortaya çıkan uçucu küllerin belirli oranlarda karıştırılmasıyla elde edilen malzemenin yine bu bölgede oluşturulan atık baraj seddelerinde ve diğer mühendislik yapılarında uygun dolgu malzemesi olarak değerlendirilebileceği ortaya konmuştur.

\section{KAYNAKLAR}

1. Schmidt, G.C., 1961. Stratigraphic Nomenclature for the Adana Region Petroleum Distric Vll. Petroleum Administration Bull, 6, 47-63.

2. İlker, S., 1975. Adana Baseni Kuzeybatısının Jeolojisi ve Petrol Olanakları, T.P.A.O. Ankara, 63 s, (Yayımlanmamış).

3. Yetiş, C., Demirkol, C., 1986. Adana Baseni Batı Kesiminin Detay Etüdü, MTA. Rapor No: 8037, 187 s., Ankara.
4. Şenol, M., Şahin, Ş., Duman, T., 1998. AdanaMersin Dolayının Jeoloji Etüd Raporu, MTA Doğu Akdeniz Bölge Müdürlüğü, Adana (yayımlanmamış).

5. Kavas, T., Çelik, M., Evcin, A., 2004. Cam Atıklarının Çimento Üretiminde Katkı Maddesi Olarak Kullanılabilirliğinin Araştırılması, Endüstriyel Ham Maddeler Sempozyumu, İzmir.

6. Sakatoğlu, S., 2002. Menekșe Köyü(Karaisalı) Killerinin Camiş Madencilik A.Ş. Atıkları ile Karıştırılarak Tuğla Yapılması Olanaklarının Araştırılması, Ç.Ü. Fen Bilimleri Enstitüsü, Maden Müh. Anabilim Dalı Yüksek Lisans Tezi, Adana.

7. Ünal, O., Uygunoğlu, T., 2004. Soma Termik Santral Atığ 1 Uçucu Külün İnşaat Sektöründe Değerlendirilmesi, Türkiye 14. Kömür Kongresi Bildiriler, Zonguldak, s.311.

8. Atanur, A., 1970. Türkiye'de Elde Edilen Uçucu Küllerin Menşeleri, Özellikleri ve Bu Uçucu Küllerin Agrega-Çimento Karışımlarında Portland Çimentosunun Bir Kısmını İkame Edebilmek İmkanlarının Araştırılması, Karayolları Gen. Müd. Araştırma Fen Heyeti Müd. Teknik Bülten Sayı 30. Ankara.

9. Alkaya, D., 2009. Uçucu Küllerin Zemin İyileștirmesinde Kullanılmasının İncelenmesi, Electronic Journal of Construction Technologies, 5 (1) 61-72.

10. Atanur, A., 1970. Türkiye'de Elde Edilen Uçucu Küllerin Menşeleri, Özellikleri ve Bu Uçucu Küllerin Agrega-Çimento Karışımlarında Portland Çimentosunun Bir Kısmını İkame Edebilmek İmkanlarının Araştırılması, Karayolları Gen. Müd. Araştırma Fen Heyeti Müd. Teknik Bülten Sayı 30. Ankara.

11. Çavuşoğlu, İ., 2008. Uçucu Küllerin Dolgu Malzemesi Olarak Kullanılması: Örnek Bir Uygulama (Çayırhan), 47(3), 3-13.

12. Çuhadaroğlu, D., Kızgut, S., Çolak, K., 2001. Çatalağzı Termik Santralı Uçucu Küllerinden Tuğla Üretim Olanaklarının Araştırılması, Türkiye 17. Uluslararası Madencilik Kongresi ve Sergisi.

13. ASTM D 854-02, 2003. Standard Test Method for Specific Gravity of Soils, In: Annual Book 
of ASTM Standards, Volume 04.08, West Conshohocken, 93-99.

14. ASTM, D 4318-00, 2003. Standard Test Method for Liquid Limit, Plastic Limit and Plasticity Index of Soils, In: Annual Book ASTM Standarts, Volume 04.08, West Conshohocken, 582-595.

15. ASTM D 422-63, 2003. Standard Test Method for Particle-Size Analysis of Soils, In: Annual Book of ASTM Standarts, Volume 04.08, West Conshohocken, 10-17.

16. ASTM D 698-00a, 2003. Standard Test Method for Laboratorycompaction Characteristics of Soil Using Standard Effort. AnnualBook of ASTM Standards. American Society For Testing and Materials, 04.08,West Conshohocken, 78-87.

17. ASTM D 3080-98, 1993. Standard Test Method for Direct Shear of Soils Under Consolidated Drained Conditions, In: Annual Book of ASTM Standards, Volume 04.08, Philadelphia, PA, 417-422. 
